\title{
The Effect of Darkness Treatment on Plasma Melatonin Concentrations and Reproductive Performance in Akkaraman Ewes
}

Emre Şirin ( $\sim$ emre.sirin@ahievran.edu.tr)

Ahi Evran Universty https://orcid.org/0000-0002-0459-9589

\section{Serhan Karakaya}

Kirsehir Ahi Evran Universitesi

\section{Uğur Şen}

Ondokuz Mayis University: Ondokuz Mayis Universitesi

\section{Research Article}

Keywords: Sheep, Akkaraman, Estrus, Darkness, Melatonin

Posted Date: March 2nd, 2022

DOI: https://doi.org/10.21203/rs.3.rs-1345845/v1

License: (c) (i) This work is licensed under a Creative Commons Attribution 4.0 International License.

Read Full License 


\section{Abstract}

Different techniques are used to achieve pregnancy out of season in sheep. These techniques are mostly performed with artificial and natural hormone injections. In this study, darkness application was carried out as a different technique. This study investigates the effect of the darkness treatment on plasma melatonin concentration and reproductive performance during the out-breeding season (April month) in the Akkaraman sheep breed. The vaginal implant device CIDR ( $0.30 \mathrm{~g}$ progesterone) in all sheep was used for return to the beginning of the follicular development (0.day). The control group $(C ; n=25)$ was synchronized by using natural and synthetic hormones. The dark group $(D ; n=25)$ was exposed to darkness for 13 hours (18:00-07:00h) in a fully environmentally controlled shelter. Ewe was taken blood in a specific program, and melatonin hormone concentrations were determined in Elisa device. At the end of darkness application, melatonin hormone concentration in the darkness applied group $(90.83 \pm 29.27$ $\mathrm{pg} / \mathrm{ml})$ was higher than the control group $(66.58 \pm 21.05 \mathrm{pg} / \mathrm{ml})(\mathrm{P}<0.01)$. At the end of the experiment, melatonin concentration was higher in the darkness applied group $(89.30 \pm 29.57 \mathrm{pg} / \mathrm{ml})$ than the control group $(54.44 \pm 22.97 \mathrm{pg} / \mathrm{ml})(P<0.01)$. Reproductive characteristics were not different between the groups $(P>0.05)$. According to these results, it has been shown that melatonin hormone concentrations may change with the application of darkness during the out-breeding season in sheep, and it is possible to estrus synchronize with this method in the Akkaraman sheep breed.

\section{Introduction}

Sheep is a breeding species depending on the season. However, they may show estrus in tropical regions throughout the year and periodically (Jainudeen ve Hafez, 1983). In the northern hemisphere, including Turkey, sheep have seasonal breeding properties. The incidence of estrus in ewes in Turkey is concentrated in the last period of the summer and autumn. The interactions between the hormones produced by the hypothalamus, anterior pituitary, and ovaries play a role in regulating the estrus cycle (Roche, 1996; Hunter et al., 2004). GnRH is secreted from the hypothalamus, FSH, LH, prolactin, and oxytocin secreted from the pituitary gland, estrogen secreted from ovaries, and PGF2a secreted by uterine endometrium. In addition, the relationship between the uterus and ovarium is essential because of the secretion of PGF2a, which causes the destruction of the corpus luteum and stops the synthesis of progesterone hormone (Bartlewski, 2001; Davies, 2005). The effects of photoperiodic on seasonal reproductive activity in sheep and these effects are mediated by the pineal gland and its hormone melatonin (Gökdal ve Baş, 1996). The pineal gland shows a rhythm of night and day. It also ensures the adaptation of the creature against light changes production and synthesis start with darkness and ends with light. Light stimuli cause fluctuations in the amount of melatonin. The prolongation of the light period or the sudden emergence of light stops melatonin production (Neils, 1997; Yilmaz, 1997).

For this reason, melatonin has been given a symbolic name as a biochemical descriptor of darkness (Neils, 1997). Melatonin hormone is a type of neuronal hormone synthesized from the pineal gland due to photoperiod. This mechanism takes place under the control of the nervous system. Melatonin released from the pineal gland is another hormone that effectively initiates the estrus cycle (Zhdanova, 2005). 
Light signals from the retina are also reduced due to reduced daylight. As a result, the level of melatonin released from the pineal gland begins to increase (Zarazaga et al., 2010). As a result of photoperiodic changes, the melatonin hormone is secreted by stimulating suprachiasmatic nuclei, light-sensitive cells.

The melatonin hormone influences the hypothalamus and increases the gonadotropin-releasing hormone produced in the neurosecretory cells through the hypothalamus-pituitary portal veins and sinusoidal capillaries. Afterward, it stimulates gonadotropin cells and causes the secretion of FSH and LH, which enables the development of follicles (Senger, 1995).

Thus, seasonal reproductive activity begins. Starting with the hormone melatonin, $\mathrm{GnRH}, \mathrm{FSH}$, and LH stimulate the release of estrogen hormone, progesterone, and inhibin from the ovary. These secreted hormones control the release frequency of $\mathrm{GnRH}, \mathrm{FSH}$, and $\mathrm{LH}$ by positive and negative feedback mechanisms (Ekiz, 2005). There are synchronization practices that enable sheep to show estrus during and outside the breeding season. Progestagens, estrogens, PGF $_{2 a}$ and its analogs, gonadotropins such as PMSG, GnRH, and $\mathrm{hCG}$ are widely used combinations in estrus synchronization practices (Akçapınar et al., 1998: Yaralı and Karaca, 2004). However, there are limited studies on estrus synchronization due to the change in plasma melatonin concentrations with the dark application, especially outside the breeding season. This study aimed to investigate the effect of the dark application on plasma melatonin concentration and reproductive performance in sheep's out-of-breeding season in Turkish native Akkaraman sheep breeds.

\section{Materials And Methods}

In this study, 50 heads of Akkaraman ewe were used. This study was carried out in April, which is considered as out-of-breeding season. All ewes were injected with one cc of $\mathrm{PGF}_{2 a}$ intramuscular (IM) at the beginning of the experiment for the luteolysis of the corpus luteum. One week after the injection, ewes were divided into two groups (control and darkness group) in equal numbers. Ewes in the darkness group $(n=25)$ were subjected to dark application for 13 hours $(18: 00-07: 00 h)$ in a fully environmentally controlled shelter. Darkness application was continued for 12 days. Ewes in control groups $(n=25)$ were subjected to estrus synchronization using the vaginal implant device CIDR containing natural progesterone ( $0.30 \mathrm{~g}$ progesterone). The CIDR device was removed after 12 days and immediately, $600 \mathrm{IU}$ PMSG were injected as IM. The mating process was carried out for four days after the end of the applications, and ewes were introduced to Akkaraman rams. The mating was monitored to determine estrus rates. The birth type of lambs was recorded immediately after lambing. Gestation rate; (ewes lambing/ewes mated) $\times 100$, lambing rate; (lambs born/ewes mated) $\times 100$ and litter size; (lambs born/ewes lambing) were calculated for ewes in experimental groups. Following lambing, all lambs were kept with their dams in the fold for two weeks.

The change in melatonin hormone was determined by taking $8 \mathrm{ml}$ of blood from the jugular vein with the help of a vacutainer from all animals. In both groups, blood samples were taken from the jugular vena of the ewes on CIDR or darkness application (day 0), at the time of CIDR withdrawal or end of the darkness application (day 12), and mating (day 16). Blood samples were centrifuged at $400 \mathrm{rpm}$ at $+4^{\circ} \mathrm{C}$ for 10 
minutes. The resulting plasma was then stored at $-20^{\circ} \mathrm{C}$ until the analysis day divided into $1 \mathrm{ml}$ of tubes. Determination of melatonin concentrations in blood was carried out by ELISA (Competitive-ELISA). With the Curve Expert 1.3 software recommended by the kit manufacturer, the absorbance values of the serum and standards were compared, and the concentrations of the serum were calculated by reading them at $450 \mathrm{~nm}$ wavelength by creating a standard curve. All data obtained from the study were analyzed using SPSS 20.0 package program. The suitability of the data for variance analysis was evaluated with the Levente variance homogeneity test.

\section{Results}

Plasma melatonin concentrations of Akkaraman ewes, treated with darkness or CIDR, at the beginning and end of treatments and the end of mating are present in Fig. 1.

There was no difference between the groups regarding melatonin hormone concentrations at the beginning of treatments, but darkness treatment increased $(P<0.01)$ the plasma melatonin concentration compared to CIDR at the end of the treatment period. Similarly, plasma melatonin concentrations of ewes treated with darkness were significantly higher $(P<0.01)$ than those of CIDR at the end of mating.

Plasma melatonin changes of Akkaraman ewes from beginning treatments to the end of mating are present in Fig. 2. It was determined that the change in melatonin hormone concentration between the beginning and the end of the treatments was significantly greater $(P<0.01)$ in the dark treated ewes $(16.2$ $\pm 2.2)$ than those of the control ewes $(2.5 \pm 0.9)$ group. Ewes in the control group had significantly decreased $(P<0.01)$ in plasma melatonin hormone concentration from the end of the treatments to begin of the mating compared to ewes in darkness groups (-12.1 \pm 1.1 vs. $-1.5 \pm 0.2)$. Similarly, the change in melatonin hormone concentration between the beginning of the treatments and the end of the mating was lower $(P<0.01)$ in the control ewes $(-9.6 \pm 1.0)$ than those of the darkness ewes $(14.6 \pm 1.3)$.

Fertility characteristics of ewes in control or darkness groups are given in Table 1. According to these results, no difference was found between the experimental groups in terms of estrus rates, gestation rates, lambing rate, and liter size.

Table 1

Fertility characteristics of ewes in control or darkness groups

\begin{tabular}{|lll|}
\hline Traits $(\%)$ & Control & Darkness \\
\hline Estrus rate & $23 / 25(92)$ & $22 / 25(88)$ \\
\hline Gestation rate & $22 / 25(88)$ & $20 / 25(80)$ \\
\hline Lambing rate & $22 / 25(88)$ & $20 / 25(80)$ \\
\hline Liter size & $22 / 22(100)$ & $20 / 20(100)$ \\
\hline
\end{tabular}




\section{Discussion}

Photoperiodism has effects on the seasonal reproductive activity of sheep. These effects occur through the pineal gland and melatonin synthesized from this gland. With the understanding of this situation, a new approach has emerged regarding reproduction in sheep. This approach revealed that could control seasonal reproductive activity in sheep and estrus can be created outside of the typical breeding season (Gökdal ve Baş, 1996). The mammalian pineal gland transforms external signals, principally light, into an endocrine compound, melatonin, which is only secreted during the dark phase. In seasonal reproductive animals, especially sheep, the duration of melatonin secretion indicates day-length to the animal, which affects the reproductive system (Karsch et. al., 1980).

As the length of the day begins to shorten, the pineal gland begins to secrete melatonin thanks to the optic nerves. There are different approaches to the mechanism of action of melatonin. Melatonin hormone causes physiological changes in the gonads by affecting the adenohypophysis through the hypothalamus (Kaymakçı, 1996). Melatonin hormone has been reported to initiate ovarian activity by stimulating gonadotropin synthesis. The effect of photoperiod emerges by stimulating gonadotropin release via melatonin (Arendt, 1986). Accordingly, estrus appears in sheep. Melatonin is having a decisive impact on estrus in sheep. Based on this information, it can be said that the activity of the pineal gland and, therefore, melatonin synthesis is determinant in oestrus synchronization in the breeding season and outside the breeding season in sheep.

In our study, the possibility of changing the amount of synthesis of melatonin hormone by changing the duration of lighting effects investigated the activity of the pineal gland and, consequently, whether oestrus can be synchronized in sheep outside the breeding season. The results obtained in our study showed that the concentration of the melatonin hormone synthesized from the pineal gland in the blood increased with increasing the dark period. The results obtained in our study showed that with increasing the dark period, the concentration of the melatonin hormone synthesized from the pineal gland increased in the blood. It is known that long-term use of synthetic hormones in oestrus synchronization, especially outside the reproductive season, causes cyst formation in the ovaries (Christman et al., 2000). In order to avoid such situations, the dark application can be used as an alternative in oestrus synchronization.

As a result, the fertility results obtained by applying dark in estrus synchronization outside the breeding season showed that it could be used as an alternative to estrus synchronization methods using synthetic or natural hormones in Akkaraman sheep breed.

\section{Conclusion}

In conclusion, the results of the present study suggest that outside the breeding season, darkening can be used as an alternative method for synchronizing the heat of Akkaraman sheep.

\section{Declarations}




\section{Funding}

The authors acknowledge the financial support by Ahi Evran University (ZRT. A3.17.002) to carry out this study.

\section{Conflict of interests}

The authors declare that there is no conflict of interests.

\section{Ethics approval}

Ahi Evran University Ethical Clearance Committee approved the study. The research involved animals and was approved by the Ethical Committee.

\section{Consent to participate}

The farmer were informed about the research and agreed to participate. The farmer engaged gave their informed consent prior to the study.

\section{Consent for publication}

All authors approved the manuscript for publication.

\section{Availability of data and material}

Data is available.

\section{Code availability}

Not applicable

\section{Authors contrubutions}

EŞ: designed experiments; EŞ, SK, UŞ: methodology, data analysis: EŞ, SK, UŞ : writing initial paper; EŞ, UŞ, supervision.

\section{Acknowledgement}

We would like to thank Dr. Erkan Pehlivan for her contributions in hormone analysis.

\section{References}

1. Akçapınar, H., Özbeyaz, C., Ünal, N., Avcı, M. 1998. Kuzu Eti Üretimine Uygun Ana ve Baba Hatlarının Geliştirilmesinde Akkaraman, Sakız ve Kıvırcık Irklarından Yararlanma İmkanları. I. Akkaraman Koyunlarında Döl Verimi, Akkaraman, Sakız x Akkaraman F1 ve Kıvırcık x Akkaraman F1 Kuzularda Yaşama Gücü ve Büyüme. Tr. J. of. Veterinary and Animal Sciences, Tübitak. 24: 71-79 
2. Arendt, J., 1986. Role of the pineal gland and melatonin in seasonal reproductive function in mammals. Oxford Reviews of Reproductive Biology 8:266-320

3. Bartlewski, P.M. 2001. The Relationships between Ovarian Antral Fallicle Dynamics, Luteal Function and Endocrine Variables in Ewes, PhD thesis, Department of Veterinary Biomedical Sciences, Western College of Veterinary Medicine, University of Saskatchewan, Saskatoon, Saskatchewan, Canada.

4. Christman, S.A, Bailey, M.T., Head, W.A., Wheaton J.E. 2000. Induction of ovarian cystic follicles in sheep. Domest Anim Endocrin, 19: 133-146.

5. Davies, K.L. 2005. Ovarian Antral Follicular Dynamics and Regulation in Sheep, MSc thesis, Department of Veterinary Biomedical Sciences, Western College of Veterinary Medicine, University of Saskatchewan, Saskatoon, Saskatchewan, Canada.

6. Ekiz, E. 2005. Kıvırcık Irkı Koyunlarda Sıfat Mevsimi İçinde ve Dışında Östrus Davranışları ile Hormon Düzeylerinin İncelenmesi. İstanbul Üniversitesi Sağlık Bilimleri Enstitüsü, Fizyoloji Anabilim Dalı, Doktora Tezi, İstanbul.

7. Gökda,I Ö., Baş, S. 1996. Koyunlarda Üremenin Denetiminde Melatonin İmplantların Kullanma Olanakları, Yüzüncüyıl Üniversitesi Ziraat Fakültesi Dergisi, Cilt: 6, Sayı: 2.

8. Hunter, M.G., Robinson, R.S., Mann, G.E., Webb, R. 2004. Endocrine and paracrine, control of follicular development and ovulation rate in farm species. Animal Reprod. Sci., 82-83, 461-477.

9. Jainudeen, M.R., Hafez, E.S.E. 1983. Sheep and goats. In: Hafez ESE. Editor, Reproduction in Farm Animals. 6rd Ed., Philadelphia, Lea\&Febiger; 6:330-342.

10. Karsch, F.J., Goodman, R.L., Legan, S.J. 1980. Feedback basis of seasonal breeding: test of an hypothesis. J.Reprod. Fertil, 58: 521-535.

11. Kaymakçı, M. 1996. Üreme Biyolojisi. E.Ü. Zir. Yay., No: 503. İzmir.

12. Neils, P.C. 1997. Compendium of Animal Reproduction. Intervet International B.V. ISBN:9080188654.

13. Roche, J.F. 1996. Control and regulation of folliculogenesis- a symposium in perspective. Reviews J. Reprod and Fertil., 1, 19-27.

14. Senger, P.L. 1995. Pathways to Pregnancy and Parturition, Current Conceptions, (ISBN: 0965764826), $373 \mathrm{p}, \mathrm{ABD}$.

15. Yaralı, E., Karaca, O. 2004. Kıvırcık Koyunları Farklı Senkronizasyon Uygulamalarında Kuzu Üretimi ile Kuzuların Canlı Ağırlık ve Bel Gözü Ultrasonik Ölçüm Parametreleri. 4. Ulusal Zootekni Bilim Kongresi, 01-03 Eylül. Isparta.

16. Yılmaz, B. 1997. Hormonlar ve Üreme fizyolojisi, Ankara Üniversitesi Veteriner Fakültesi, Fizyoloji Anabilim Dalı, Ankara, 586 s.

17. Zarazaga, L.A., Gatica, M.C., Celia, I., Guzmána, J.L., Malpaux, B. 2010. Effect of artificial long days and/or melatonin treatment on the sexual activity of mediterranean bucks. Small Rum Res., 93: 110118.

\section{Figures}


$\multimap-$ CIDR $\neg-D A R K N E S S$

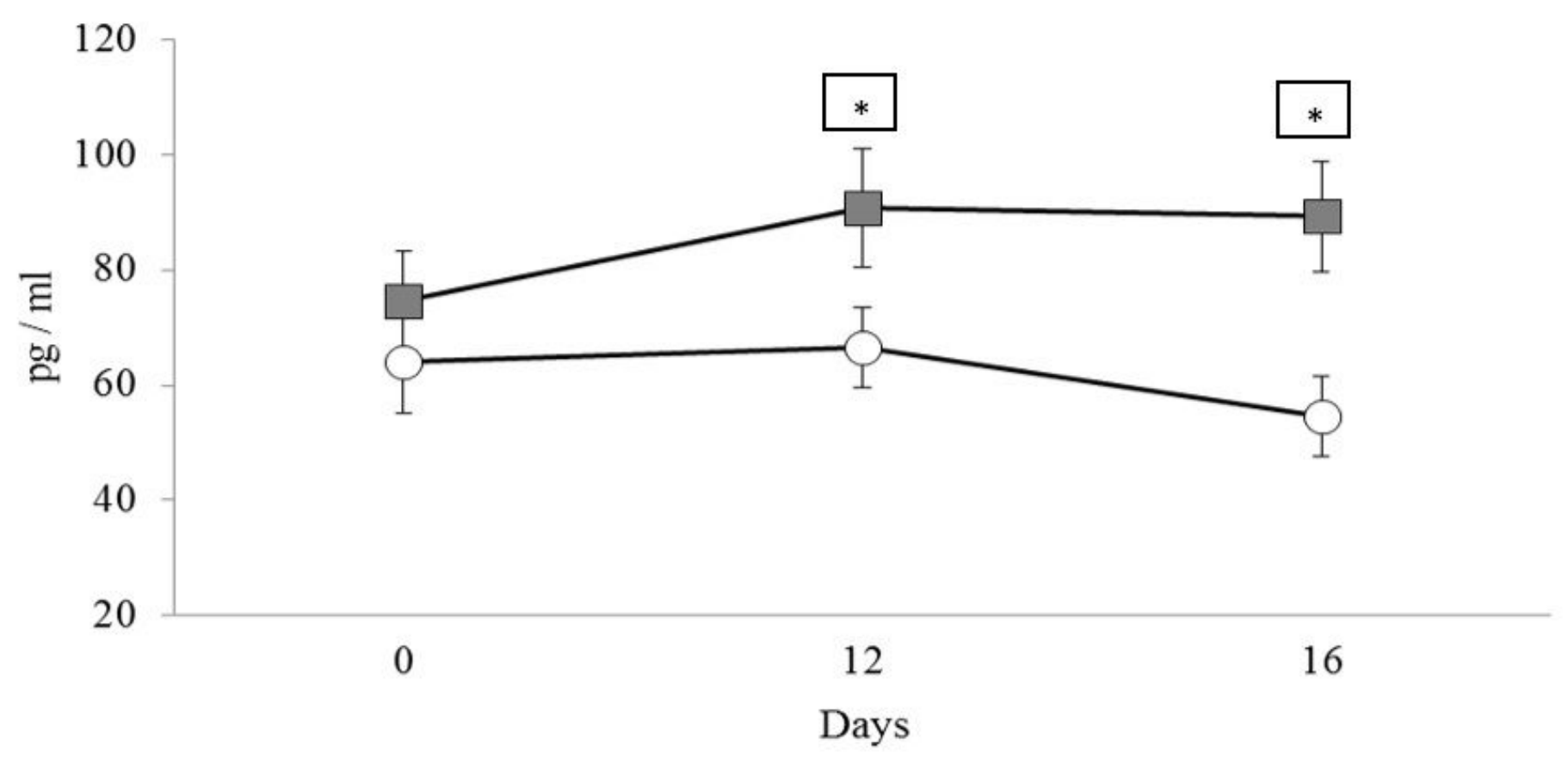

\section{Figure 1}

Plasma melatonin concentrations of Akkaraman ewes, treated with darkness and CIDR, at the beginning (day 0 ) and end (day 12) of treatments and the mating end (day 16). ${ }^{*} \mathrm{P}<0.01$. 
$\square$ CIDR $\square$ DARKNESS

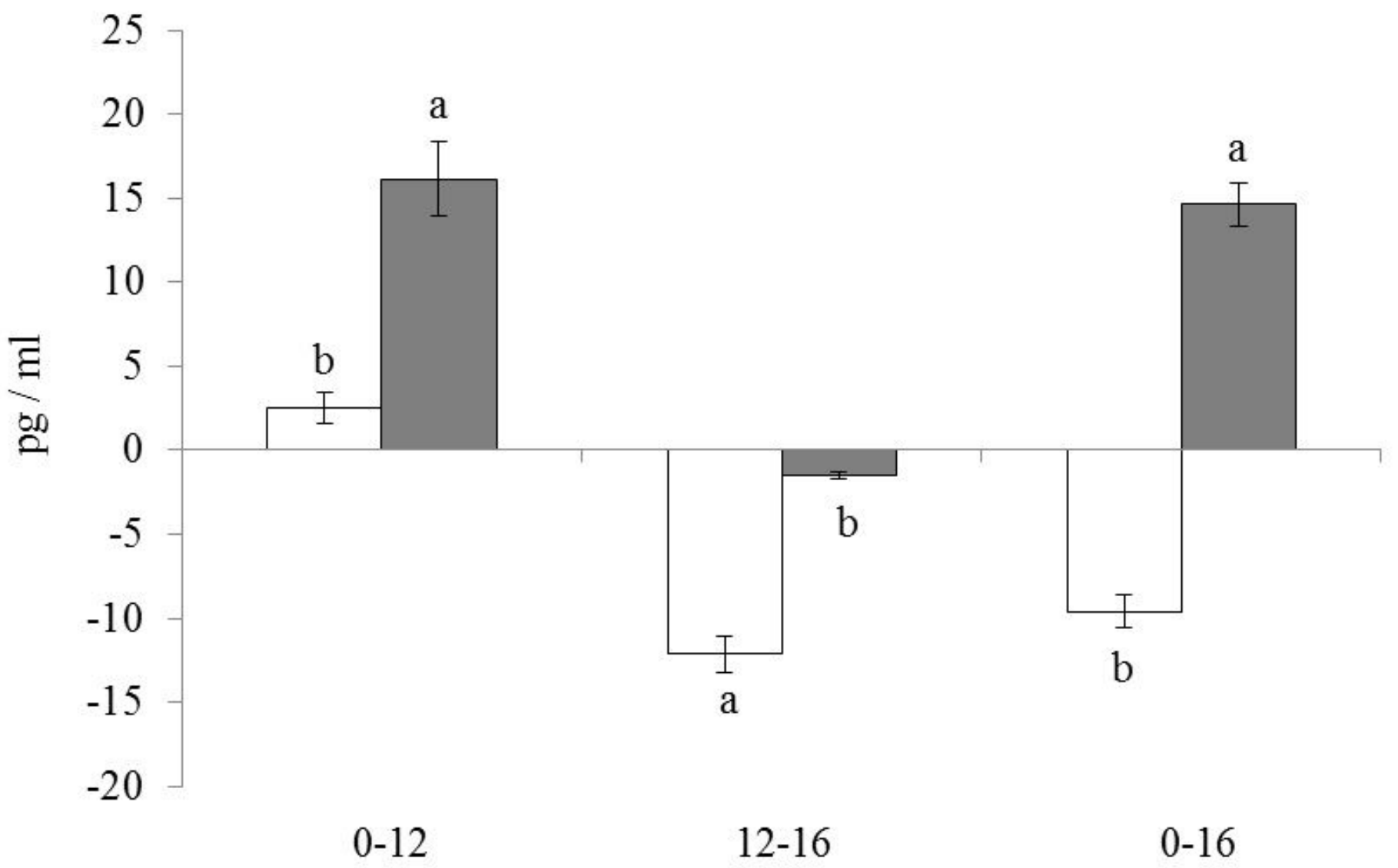

Figure 2

Plasma melatonin changes of Akkaraman ewes from beginning treatments to mating. ${ }^{a, b} P<0.01$. 